\title{
SORRISO: A PUBLICIDADE DA ODONTOLOGIA MODERNA
}

Ginger Baranhuk Rabelho de MELLO; Sarah SEHN; Paulo Cesar GONÇALVES

Em pleno século $X X I$, toda pessoa tem o direito de querer ser mais bonita e a Odontologia pode ajudar, através do processo de transformação do sorriso - cartão de visita incontestável - através da correção do tamanho, do formato e da cor dos dentes, com técnicas de clareamento e aplicação de facetas de porcelana, alterando o sorriso, sem apagar as características de cada rosto respeitando a harmonia e a beleza natural de cada um. O Objetivo deste trabalho é auxiliar o cirurgião-dentista a fazer uso de técnicas como a da fotografia e da informática, para auxiliar na apresentação de seu trabalho, e ajudar na comunicação entre o dentista e seu paciente, mostrando as inúmeras possibilidades de tratamento que a odontologia estética e suas novas técnicas e materiais podem fazer por ele. 